\title{
A Era dos Desastres no Brasil: da fase agônica da democracia eleitoral à sobrevida do capitalismo rentista
}

\author{
The Age of Disasters in Brazil: from the agonizing phase \\ of electoral democracy to the survival of rentier capitalism \\ La era de los desastres en Brasil: de la fase agonizante de la \\ democracia electoral a la supervivencia del capitalismo rentista
}

Norma Valencio $^{1}$

\section{Resumo}

VALENCIO, N. A Era dos Desastres no Brasil: da fase agônica da democracia eleitoral à sobrevida do capitalismo rentista. Rev. C\&Trópico, v. 45, n. 2, p. 105-134, 2021. DOI: https://doi.org/10.33148/cetropicov45n2(2021)art7

Nas últimas décadas, o Brasil tem sido palco de uma preocupante regularidade de ocorrência de desastres, o que suscita indagações acerca de quais processos, de natureza social, têm contribuído para perpetuar e/ou incrementar o problema. As narrativas difusas que reportam os desastres como processos caóticos, devido aos elementos disruptivos da dinâmica socioespacial que os constituem bem como à ampliação do horizonte de incertezas para os grupos sociais que os vivenciam, têm justificado o acionamento tecno-político de um modus operandi de excepcionalidade na gestão pública, que se baseia numa narrativa de controle do caos e compromisso com o retorno à normalidade. Ocorre que, ambiguamente, aquilo que se anuncia como excepcionalidade vem se tornando o estado normal da gestão pública, no espraiamento e recorrência das decretações de emergências, cabendo considerar que, sob o seu manto, se aninha um projeto de poder autoritário. Sob um prisma sociológico, este artigo visa a problematizar as narrativas complementares centradas no binômio caos/normalidade e refletir como elas instrumentalizam o processo sociopolítico de esgarçamento do Estado democrático de direito ao passo que blindam a lógica do capitalismo rentista, cujo resultado seria conduzir a sociedade brasileira em direção a um ciclo de políticas públicas disjuntivas, ao esgarçamento das promessas do Estado democrático de direito e à atomização social, aqui metaforicamente denominado como sendo a Era dos Desastres no país. Essa reflexão é feita através do destaque às contribuições do debate contemporâneo, no

1 Economista, Pontifícia Universidade Católica de Campinas (1985); Mestre em Educação, Universidade Estadual de Campinas (1988); Doutora em Ciências Humanas, Universidade Estadual de Campinas (1993). Atualmente, professora sênior do Departamento e do Programa de Ciências Ambientais da Universidade Federal de São Carlos-UFSCar e professora colaboradora do Programa Interdisciplinar de Ciências Humanas e Sociais Aplicadas da Universidade Estadual de Campinas-UNICAMP. Bolsista Produtividade do CNPq. E-mail: norma.valencio@ufscar.br. Orcid: https://orcid.org/0000-0003-1855-3458 
campo crítico, que aludem ao processo sociopolítico da fragilidade da democracia eleitoral e ao processo socioeconômico de blindagem ao capitalismo rentista, componentes de uma indisfarçável pulsão catastrófica.

Palavras-chave: Democracia. Capitalismo. Direitos humanos. Desastres. Brasil

\begin{abstract}
VALENCIO, N. The Age of Disasters in Brazil: from the agonizing phase of electoral democracy to the survival of rentier capitalism. Rev. C\&Trópico, v. 45, n. 2, p. 105-134, 2021. DOI: https://doi.org/10.33148/cetropicov45n2(2021)art7
\end{abstract}

In recent decades, Brazil has been the scene of a worrying regularity in the occurrence of disasters, which raises questions about which social processes have contributed to perpetuate and/or increase the problem. The diffuse narratives that report disasters as chaotic processes, due to the disruptive elements of the socio-spatial dynamics that constitute them, as well as the broadening of the horizon of uncertainty for the social groups that experience them, have justified the techno-political activation of a modus operandi of exceptionality in public management that is based on a narrative of control of chaos and commitment to a return to normality. It so happens that, ambiguously, what is announced as an exceptionality has become the normal state of public management, in the spread and recurrence of emergency decrees, and it is worth considering that, under its mantle, a project of authoritarian power is nestled. From a sociological perspective, this article aims to problematize the complementary narratives centered on the chaos-normality binomial and reflect how they instrumentalize the socio-political process of weakening the democratic rule of law while shielding the logic of rentier capitalism, whose result would be leading the Brazilian society towards a cycle of disjunctive public policies, weakening the promises of the democratic rule of law and social atomization, metaphorically referred to here as the Era of Disasters in the country. On one hand, this reflection is made by highlighting the contributions of contemporary debate, in the critical field, which allude to the socio-political process of the fragility of electoral democracy and the socioeconomic process of shielding rentier capitalism, components of an undisguised drive for catastrophes.

Keywords: Democracy. Capitalism. Human Rights. Disasters. Brazil.

\title{
Resumen
}

VALENCIO, N. La era de los desastres en Brasil: de la fase agonizante de la democracia electoral a la supervivencia del capitalismo rentista. Rev. CઐTrópico, v. 45, n. 2, p. 105134, 2021. DOI: https://doi.org/10.33148/cetropicov45n2(2021)art7

En las últimas décadas, Brasil ha sido escenario de una preocupante regularidad en la ocurrencia de desastres, lo que plantea interrogantes sobre qué procesos, de 
carácter social, han contribuido a perpetuar y / o agravar el problema. Las narrativas difusas que reportan los desastres como procesos caóticos, por los elementos disruptivos de las dinámicas socioespaciales que los constituyen, así como la ampliación del horizonte de incertidumbre para los grupos sociales que los viven, han justificado la activación tecnopolítica. de un modus operandi de excepcionalidad en la gestión pública que se fundamenta en una narrativa de control del caos y apuesta por la vuelta a la normalidad. Ocurre que, de manera ambigua, lo que se anuncia como excepcionalidad se ha convertido en el estado normal de la gestión pública, en la difusión y reincidencia de los decretos de emergencia, y vale la pena considerar que, bajo su manto, se anida un proyecto de poder autoritario. Desde una perspectiva sociológica, este artículo tiene como objetivo problematizar las narrativas complementarias centradas en el binomio caos-normalidad y reflejar cómo instrumentalizan el proceso sociopolítico de deshilachamiento del Estado de derecho democrático al mismo tiempo que blindan la lógica del capitalismo rentista, cuyo resultado sería conducir a la sociedad brasileña en dirección a un ciclo de políticas públicas disyuntivas, al desgaste de las promesas del Estado de Derecho democrático y la atomización social, metafóricamente referida aquí como la Era de los Desastres en el país. Esta reflexión se hace resaltando los aportes del debate contemporáneo, en el campo crítico, que aluden al proceso sociopolítico de fragilidad de la democracia electoral y al proceso socioeconómico de blindaje del capitalismo rentista, componentes de un desenmascarado pulso catastrófico.

Palabras clave: Democracia. Capitalismo. Derechos humanos. Desastres. Brasil.

\section{Introdução}

Em meados de novembro de 2021, a grande mídia repercutiu uma ocorrência desalentadora havida no Parque das Aves, em Foz do Iguaçu, no Paraná. Duas onças, mãe e filhote, invadiram o recinto dedicado a uma colônia de flamingos, que contava com cento e setenta e seis indivíduos na ocasião. Essa invasão resultou em óbito de cento e setenta e dois flamingos, restando apenas quatro sobreviventes. Como predadoras que são, e famintas que estavam, as onças institivamente atacaram apenas alguns flamingos, na quantidade de alimento que supria as suas necessidades alimentares imediatas. Os demais flamingos morreram pelo terror do testemunho do ato de predação, conforme hipótese levantada pelos administradores do lugar, os quais contam com a vídeo-documentação das cenas para subsidiar a investigação técnica em curso. O testemunho do ataque do predador teria causado tamanho nível de estresse aos que não foram abatidos diretamente pelos felinos, que os levou igualmente a óbito, devido a um quadro de sofrimento animal agudo denominado miopatia de captura ${ }^{2}$. Outras

2 Dentre os veículos de comunicação que repercutiram essa ocorrência estão: O Globo (Disponível em: https://g1.globo.com/pr/oeste-sudoeste/noticia/2021/11/09/oncas-matam-172-flamingos-no-parque-das-aves-em-foz-do-iguacu-apenas-quatro-sobreviveram-ao-ataque.ghtml. Acesso em: 9 nov. 2021); o 
circunstâncias estressantes são passíveis de acionar esse tipo de gatilho metabólico, tais como em decorrência de erro de manejo em estratégias conservacionistas que envolvem a contenção e translocação de indivíduos, provocando nestes efeitos somáticos e comportamentais deletérios e irreversíveis, nos quais a musculatura das pernas consta como uma das mais afetadas (PAULA; RODRIGUES; LISBOA, 2021). A sedação dos animais capturados é uma medida recomendada na redução dos riscos à saúde desses animais nessas circunstâncias estressantes (VILA, 2015).

Não sem propósito, tais ocorrências, embora convoquem precipuamente interpretações de cunho biológico e veterinário, suscitem comparações ao que vem ocorrendo com as sociedades humanas, especialmente a brasileira. Isso porque, por aqui, estamos ainda às voltas com os desafios de uma catástrofe, a da pandemia de Covid-19, cujo gatilho esteve associado, de uma forma ou outra, a um manejo impróprio de animais silvestres algures, denotando a produção global dos riscos. A conexão do lá e do cá não se deu apenas através por meio das migrações humanas, da economia produtiva e da oferta de serviços, mas também através da disseminação de elementos disruptivos contidos nas medidas contingenciais acionadas, isto é, na nova cadeia de sentidos e de práticas que vinham responder às adversidades vivenciadas. Embora esses elementos disruptivos tenham natureza similar na escala planetária de seu espargimento - por exemplo, o coronavírus SARS-Cov2, uma dada cepa dele e seus mecanismos de propagação - as estratégias de contingenciamentos têm sido específicas para cada sociedade local, de acordo com as interpretações institucionais adotadas, os recursos materiais e humanos disponíveis assim como as predisposições sociais ali estabelecidas. Isto é, os riscos globais que o século XXI nos apresenta explicitam os desafios abissais do processo de cosmopolização (BECK, 2018), visto que as concertações multilaterais que os poderiam equacionar não prosperam o quanto deveriam, subordinadas que ainda estão às singularidades de entendimento e de ação de entes regionais, nacionais e locais. Quanto mais estes falhem em prover à sociedade local os meios de defesa requeridos, mais os riscos se multiplicam, se materializam e reforçam o mal-estar coletivo. Ademais, os riscos não se apresentam num estado puro, passíveis de controle por segmentos públicos ou empresariais especializados, mas se metamorfoseiam ao se conectarem com as crises em andamento no contexto local, como adiante abordaremos, no caso das relações de vizinhança com meganegócios.

Quando adentramos no contexto brasileiro, não há como ignorar que extensos segmentos da sociedade já vêm, há muito, padecendo por crises econômicas, sociais e políticas sucessivas e de difícil equacionamento. Assim, quando a mesma vivencia, no terreno, a manifestação de riscos globais - da pandemia à crise climática -, há um aprofundamento do sentimento de desamparo coletivo, deflagrando um estresse derradeiro similar a uma miopatia de captura. Às centenas de milhares de mortos

UOL (Disponível em: https://agora.folha.uol.com.br/sao-paulo/2021/11/oncas-matam-172-flamingos-durante-ataque-em-parque-de-foz-do-iguacu.shtml?utm_source=mail\&utm_medium=social\&utm campaign=compmail, Acesso em: 11 de novembro de 2021) e a Gazeta do Povo (https://www.gazetadopovo.com.br/parana/mais-de-170-flamingos-morrem-apos-ataque-de-oncas-no-parque-das-aves/, Acesso em: 9 nov. 2021). 
pelo Covid-19 no Brasil, restam outras tantas de mortos-vivos, nas famílias esfaceladas devido à perda de seus entes queridos, de seus arrimos econômicos, de seus projetos de vida, bem como devido ao descompromisso das autoridades com a sua recuperação psicossocial e econômica. Acuados, desorientados e impotentes pelas arbitrariedades políticas e econômicas sucessivas, não houve pernas suficientemente ágeis dos subcidadãos para escaparem. Restaram-lhes, apenas, as forças últimas para prantear as mortes precoces e evitáveis de sua rede primária, para tentar amparar os adoecidos com sequelas graves de saúde, para procurar alguma forma precária de lidar com o agravamento da insegurança alimentar e hídrica. Enfim, algo que se assemelha à perda de controle sobre a mente e as pernas, sem que seja possível vislumbrar uma reação à altura dos acontecimentos ou uma rota alternativa de fuga para evitar a continuidade de tais perversidades. É como se o metabolismo coletivo da nação tivesse colapsado.

No Brasil, a conjunção entre as formas de violências fulminantes e homeopáticas, componentes de uma mesmo projeto de barbárie, se deve a uma elite culturalmente forjada numa lógica de alienação ao sofrimento humano que se desenrola ao derredor, a qual reitera e atualiza a sua performance de indiferença social a fim de reconfirmar a naturalização das desigualdades sociais estruturais no espaço nacional (COHN, 2004; MATOS, 2004). Porém, as estratégias que lhe permite sair incólume da tragédia coletiva são aquelas que arruínam quaisquer possibilidades de mudança metabólica política e econômica em prol das vítimas. Ao avançarem com garras e dentes na jugular de grupos sujeitados, predando-os impiedosamente, tais elites anunciam, aos que testemunham os acontecimentos, que estes são igualmente uma massa desprovida de projeto factível de emancipação e que perecerão na angústia, no desnorteamento, na atomização social, enfim, no estresse coletivo estéril, que lhes impede reação equiparável à força de seus robustos predadores sociais.

Ainda que coubesse ponderar, sob uma perspectiva dialética, que as gravíssimas circunstâncias acima mencionadas, por se mostrarem insuportáveis para os expressivos contingentes sociais desumanizados, jogam luzes sobre o seu justo oposto - ou, nos termos esperançosos de Beck (2018), a experiência da catástrofe seria passível de produzir tamanho choque social que estimularia a agência dos descartados, estimulando a materialização de suas utopias -, é mister nos determos um pouco mais sobre os processos de operacionalização das crueldades, nos seus efeitos de desalento social no do tempo presente. Isso, não para que um mergulho distópico prenda-nos em pessimismo, mas porque é preciso considerar os modos de atualização dos processos de barbárie para combatê-los.

No contexto brasileiro, no qual os efeitos cumulativos de crises inesgotáveis e acontecimentos trágicos produzem um estresse coletivo inimaginável, algumas indagações, sempre presentes no debate das ciências sociais, permanecem abertas para novas respostas tentativas. Duas delas são: por que os mecanismos de acuamento social têm sido tão longevos e prósperos por aqui? Por que sequer o recrudescimento dos modos de opressão social tarda em surtir efeitos de resistência em prol de projetos emancipatórios?

Através de uma abordagem sociológica, de cunho crítico, este ensaio não pretende responder plenamente às questões acima elencadas, mas oferecer três pistas que, 
nos itens que seguem, nos parecem relevantes para a composição posterior de respostas provisórias. A primeira delas, centra-se na compreensão do processo socioambiental do país como sendo o de demarcação de uma verdadeira Era dos Desastres, na qual ganha perenidade um misto de forças sociais ambientalmente predatórias e socialmente desmobilizadoras, que atomiza e enfraquece as lutas pela garantia do bem-estar coletivo. Enquanto a destruição de recursos naturais e o inacesso a infraestruturas e serviços essenciais caminham a passos largos, suscitando uma miríade de desastres e subsunção ao modus operandi tecno-político de gestão de emergências, supressor de direitos humanos, as instituições públicas buscam apascentar os grupos sociais vilipendiados no seu adestramento para a aceitação resignada de relações de vizinhança com meganegócios, que produzem riscos socioambientais significativos, através de medidas conciliatórias e afins. A segunda, é a reconfirmação da natureza econômica e política do processo de desumanização daqueles a quem Bauman (2005) denominou como consumidores falhos, o que tem como fulcro o culto ao individualismo, através do desfazimento dos lugares, dos vínculos sociais, e da blindagem do capitalismo rentista sob o manto de uma governamentalidade neoliberal. A terceira, é o célere e reiterado descumprimento das promessas democráticas de inclusão social devido a um Estado cuja capacidade de ação se deteriora a passos largos, deslocando para o mercado muitos dos seus afazeres e, assim, indo em direção a um ciclo de políticas públicas disjuntivas. Ou seja, políticas que sequer tentam responder aos clamores do volume crescente de subcidadãos, incapacitados de garantir condignamente, e por si mesmos, os seus mínimos vitais e sociais. Como presas fáceis do populismo de diferentes matizes ideológicos, performam politicamente apenas para garantir, por algum tempo, a democracia de fachada, regime por aqui reduzido apenas a processos eleitorais, após os quais as deliberações governamentais reforçam as diretivas em desfavor da cidadania. É na junção dessas pistas que vemos os encurralados sofrerem ataques socioeconômicos contundentes, no cerco de rompantes autoritários de agentes públicos e tendo como pano de fundo a incontestabilidade do modo mais virulento de acumulação, o do dinheiro-mercadoria. Em última instância, argumentamos que, no Brasil, a Era dos Desastres se inicia menos pelos eventos extremos da natureza, que se proliferarão devido à crise climática, e mais como a faceta espoliadora do capitalismo e perversa da política.

\section{O Brasil na Era dos Desastres: das excepcionalidades administra- tivas às precariedades sociais normalizadas}

Considerando o sentido de Eras não por uma perspectiva geológica, em suas alargadas dimensões espaciotemporais, mas por uma perspectiva histórico-nacional contemporânea, tendo como pano de fundo a economia-mundo, não é desarrazoado supor que o Brasil esteja adentrando em uma Era dos Desastres. Isto é, num período histórico caracterizado por processos socioambientais disruptivos sucessivos, os quais são deflagrados por significativos desarranjos e desarmonias entre as aspirações de diferentes setores da sociedade, impossibilitando a garantia de condições locativas e 
materiais adequadas de existência a todos. Disso resultaria a precarização econômica dos mais frágeis, sua atomização social e imprevisibilidade quanto ao seu futuro próximo decorrente da somação de perdas e danos em níveis insuportáveis. Abranches (2017) se refere a uma Era do Imprevisto, buscando caminhos de utopias realizáveis, tal como Santos (2019), com quem dialoga. Sobretudo, é na escala espacial e temporal miúda da vida social, que têm sido plantadas sementes de mundos imaginados, o que é por ele levado em conta. Mas, a nosso ver, tem havido processos sociais que, em uma escala maior, têm levado à rápida esterilização do solo das possibilidades emancipatórias, o que ainda merecer espaço de reflexão para mobilizar a indignação coletiva na direção emancipatória. Considere-se, por exemplo, os benefícios de mobilização social recente oriundos do debate científico que sacramentou a incorporação do Antropoceno como parte constituinte da periodização histórico-geológica. Quando principais loci de concertação multilateral passaram a tê-lo em conta para interpretar de que forma as transformações econômicas, a dinâmica demográfica e as alterações ecossistêmicas estão implicadas na perda de capacidade de suporte do planeta, isso revitalizou as pressões sociais sobre os governantes. As reuniões do Painel Intergovernamental de Mudanças do Clima (IPCC) constituíram-se como as arenas mais emblemáticas para fazer uma discussão e propugnar uma agenda de compromissos baseado na ideia de Antropoceno, com um público renovado de contestadores, nas ruas, para lembrar aos decisores que estes estão sendo monitorados. Entretanto, a dinâmica política no tema tem sido jogo lento, de avanços e recuos nos compromissos institucionais mútuos, tornando as deliberações tímidas diante dos diagnósticos científicos disponibilizados e às pressões sociais correntes. Conforme o jogo se desenrola, mais claramente se vê que as balizas institucionais nacionais adotadas pelos países que mais contribuem na emissão de gases de efeito estufa e nos efeitos cumulativos dos riscos relacionados ao aquecimento global persistem o que, explícita ou tacitamente, indica reiterada proteção aos meganegócios socioambientalmente predatórios. Desse modo, não há efetiva disposição colaborativa entre as autoridades nacionais para uma pactuação multilateral de peso, com estímulos a metamorfoses rápidas de seus processos produtivos e de urbanização ou, ainda, através da revisão de permissões para certas atividades de cunho extrativista, produtivo ou de distribuição e consumo de bens e serviços que gerem efeitos ambientais danosos. Alguns decisores alegam poder alterar apenas gradativamente o ritmo de seu modelo de desenvolvimento sem, contudo, mexer na sua lógica organizativa, a fim de preservar os interesses dos agentes econômicos expressivos implicados e, de quebra, manterem intacta a sua legitimidade política junto aos mesmos. Esse acordo de cavalheiros, por assim dizer, lança mão de toda a arte diplomática, dos dispositivos legais disponíveis - ou de uma leitura enviesada destes -, de uma oratória bem calculada e sedimentada na apresentação de artefatos espetaculares que já estariam inseridos no seu território nacional, a indicar compromissos em andamento com a sustentabilidade ambiental, para ceder o menos possível às transformações necessárias.

Em suma, embora abundem evidências provindas dos esforços conjugado de atores científicos e técnicos, bem como daqueles provindos de ongs e movimentos 
sociais, de que uma mudança de paradigma econômico é requerida para lidar com os riscos globais, como o das mudanças climáticas, persiste a normalização das práticas de acumulação dilapidadoras do patrimônio ambiental. Por mais que se denuncie a insustentabilidade do capitalismo, pela impossibilidade lógica de que este se reveste para cumprir uma promessa de responsabilidade ambiental (MARQUES, 2018), as os que teimam em jogam todas as fichas na continuidade desse modo de produção, o que, então, o legitima, levando a um ponto de não-retorno vários ecossistemas e formas de vida, incluso os riscos de sobrevivência da própria espécie humana. Assim, de um lado, parece plausível supor que, se os compromissos multilaterais com os cuidados ecossistêmicos permanecem inconvincentes, insuficientes ou, ainda, considerados desimportantes pelas autoridades constituídas que os precisaria materializar em ações tempestivas, o desenrolar do Antropoceno não encontrará obstáculos que contenham, à altura, as catástrofes previstas. E que, por carregarem componentes distintos, intercambiáveis, dinâmicos e complexos, poderão evoluir para conformações inéditas e imprevisíveis, o que exigirá um esforço incremental incomum para apoiar a criatividade humana e a solidariedade a fim de acelerar o ciclo de inovações tecnológicas e de mudanças atitudinais coletivas, incluindo a adoção de novos mecanismos de pressões sociais para calibrar as responsabilidades empresariais e institucionais em consonância com os desafios imensos que se apresentam, incluindo a revisão do modo de produção no qual organizamos a atividade econômica global. As características sistêmicas e agravadas dos desastres deflagrados no Antropoceno incidem adversamente sobre os lugares consolidados e, mais ainda, sobre aqueles precários; deflagra novos problemas de saúde pública sem que tenha sanado os anteriores; recrudesce as desigualdades sociais; aprofunda os percalços nas migrações de extensos grupos sociais desamparados, discriminados e perseguidos, os quais se deparam com barreiras intransponíveis à sua entrada no novo espaço onde aspiram recomeçar a vida e a despeito da normativa multilateral que prevê acolhê-los; acelera a ameaça a espécies da flora e da fauna assim como prejudica a produção de alimentos e o acesso à água potável. Esse elenco de problemas, que entrelaçam dimensões climáticas com a competição assimétrica por recursos escassos, com a deflagração de guerra para controle de territórios viáveis, com a expulsão ou extermínio dos indesejáveis, dentre outros, pode demarcar um período sem precedentes de normalização de barbáries, seja pela forma como poderá se desenrolar, como pelos conteúdos que as justificarão.

Por outro lado, a antevisão desse cenário dantesco, que vem se materializando, tem servido de mote para a esperançosa teoria da metamorfose, lançada por Beck (2018), segundo a qual estaríamos vivenciando um fenômeno global no qual não é mais possível supor que alguma coisas mudem enquanto outras permanecem como sempre foram. Ao contrário disso, o conjunto de relações sociais extraterritoriais, de compartilhamento de interpretações sobre os problemas comuns, de produção de novas redes de suporte e de estratégias originais de mobilização indicaria a adoção progressiva de uma perspectiva cosmopolita a qual, colidindo com os interesses nacionais e locais arcaicos, propugnariam transformações radicais e integrais na vida social, ou seja, seriam efeitos colaterais positivos advindos dos males vivenciados, argumenta o autor. 
Ainda que se possa presumir que essa configuração tenha viabilidade histórica - no caso em tela, que do recrudescimento de uma racionalidade socioambientalmente perversa possa aflorar disposições num sentido oposto, ensejando a organização social de algo inteiramente novo, que escapa da perspectiva de controle institucional nacional -, a ação cosmopolizada há de encontrar, pelo caminho, barreiras culturais, políticas e físicas que não facilitarão as metamorfoses pretendidas. O modo como a vida social se desdobraria de um lugar ao outro de crenças, normas, práticas e aspirações exigiria, a nosso ver, a identificação do tipping point, isto é, do ponto crítico, cuja inconformidade coletiva produzia uma ação mobilizadora ímpar para promover alterações drásticas na organização social. Esse ponto de ruptura poderia ser as guerras, como também os desastres, isto é, as tensões e/ou privações tão acentuadas que, por não comportarem devires aceitáveis, abririam espaço para utopias realistas (SANTOS, 2019).

Porém, há que se ponderar que os Estados nacionais, embora definhantes, são aqueles que, nos seus estertores, mais adquirem feições autoritárias para acobertar as suas deficiências de visão e operacionais, cerceando a agência de seus críticos. Ademais, desresponsabilizam-se pelo processo de vulnerabilização (ACSELRAD, 2006) que suas políticas induzem, caldo no qual os desastres tendem não apenas a ser recorrentes -expostos que estão os subcidadãos a todo tipo de perigos, que se multiplicam e fazem composições sinérgicas -, mas também banalizados, tomados institucionalmente como um dado qualquer de uma realidade intransponível. Assim naturalizados, os desastres perdem a sua significação experiencial como ponto de ruptura passível de conduzir a modalidades emancipadas de projetos coletivos de vida. Melhor dizendo, os desastres têm sido manejados institucionalmente para estabelecer um patamar ainda mais profundo de dependência do Estado e de reforço das práticas assistencialistas, que são o feno para rebanhos apascentados por retóricas populistas de diferentes matizes ideológicos, não deixando espaço para o incentivo à autonomia econômica, à inventividade e à valorização de recursos de voz.

O Brasil tem pavimentado um caminho na direção de uma Era dos Desastres. Isto é, delineando um período histórico sociopolítico e socioambientalmente marcado centralmente pela regularidade de ocorrência de desastres, os quais têm nexos, mas ultrapassam, as gestões governamentais. Nesse período, subjazem três ambiguidades não desprezíveis, quais sejam: (a) a dos desastres se apresentarem, no imaginário social, como manifestação de processos caóticos - portanto, que partem de uma mudança mínima de rota para inscrever uma trajetória não previsível - enquanto são operacionalizadas institucionalmente medidas de resposta através de procedimentos padronizados, baseados numa narrativa de compromisso com o retorno à normalidade, isto é, do retorno ao ponto inicial onde novos eventos disruptivos se encontrarão com os grupos vulnerabilizados, compondo, mais do que um círculo vicioso, uma espiral de desproteção social; (b) aquilo que se anuncia como excepcionalidade no modo de gestão da coisa pública vem se tornando o estado normal da administração estatal, na medida em que há um espraiamento e recorrência das decretações de emergências e (c) as figuras de poder, cuja inaptidão administrativa, descompromisso 
social e/ou priorização de interesses particulares são elementos constitutivos de seu despreparo para evitar os desastres, são aqueles que modulam instrumentalmente as ações assistencialistas para revitimizar os grupos sociais afetados e fazer caber a gestão do drama social em seu projeto de manutenção ou ascensão política. Muito já foi escrito e evidenciado sobre as regularidades acima mencionadas e/ou sobre casos emblemáticos (ANAZAWA; CARMO, 2021; SIQUEIRA; MALAGODI, 2013; DUTRA, 2018; VALENCIO, 2012; VALENCIO; SIENA; MARCHEZINI, 2011), de modo que aqui o que nos resta é reiterar que o binômio caos-normalidade esconde um problema distinto daquele amplificado por narrativas técnicas ou de senso comum.

Também ambiguamente, há um calculado grande salto para o caos - expressão cunhada por Tavares (1985) - fruto de um processo econômico e político que vampiriza as classes subalternas, lhes extraem a energia vital, cerceia os seus caminhos de autonomia e os leva ao colapso. Nada há para se espantar que as periferias urbanas e as moradias subnormais sejam as primeiras a serem carreadas pela lama e pelas águas pluviais no período chuvoso; que os pequenos produtores, de base familiar, sejam os primeiros privados do acesso à água para irrigar suas plantações e dessedentar seus rebanhos durante um período de estiagem; que haja comunidades indígenas passando por insegurança alimentar em níveis críticos e assim por diante. As vítimas preferenciais dos desastres são as que viram normalizadas as suas condições de marginalização social e cuja infinidade de descompensações sociais as levam a uma progressiva de desumanização. O desastre - por vezes, vivenciado recorrentemente -, desorganizam as bases materiais de sobrevivência dos afetados, desfazem seus vínculos sociais, humilham-nos em abordagens técnicas violentas e pelo acolhimento insuficientemente prestado, retira-lhes quaisquer certezas e controle sobre a rota de seu presente e de seu futuro. O modus operandi institucional daquilo que é concebido como normalidade é o que produz o caos experiencial enquanto as circunstâncias adversas, de imprevisibilidade, incerteza e desorganização da vida das vítimas deflagram um quadro sistemático de dependência destes em relação ao auxílio estatal, na esperança de que isso possibilite o seu reerguimento. Porém, esperança vã, pois isso retroalimenta a dinâmica política e socioambiental que as conduzem ao próximo desastre, quando o seu mundo desmorona novamente. Nestes termos, a consolidação de uma Era dos Desastres está garantida no referido país não apenas porque eventos extremos da natureza tendam a se propagar mais frequentemente, como efeito de mudanças do clima, mas porque essas crises envolvem patologias estruturais do sistema social e econômico e, num horizonte mais alargado de compreensão, se referre à crise do Estado moderno, assentada na corrosão de seus dois pilares, que são a democracia representativa e os limites da economia rentista (BAUMAN; BORDONI, 2016).

Por fim, mas não menos importante, a despeito da categoria tempo ser um pilar para a suposição de nascimento de uma Era dos Desastres no Brasil, aqui ela não é tomada exatamente de forma objetiva e linear, mas em sua construção social moldável, que permite extensões e intensidades particulares. O calendário, assim como o relógio, tornaram-se imprescindíveis para pautar as relações sociais, mas a vivência 
de desastres é uma das experiências humanas que alteram substantivamente a relação com o tempo, pois a tragicidade dos acontecimentos depende de como cada qual organiza a experiência frente à memória de sua trajetória e as imagens projetadas sobre o seu devir (ELIAS, 1998). É dizer, diferentes extensões de tempo, para trás e para frente, serão resgatadas por cada uma das vítimas para compor o sentido daquele acontecimento dramático para si mesmas, o que ultrapassa e se descola daquilo que pontualmente é percebido por governantes e/ou grupos técnicos e voluntários que atuam na emergência ou pelo testemunho de terceiros em geral. O campo da problematização da experiência social que configura um desastre é vasto (OLIVEIRA, 2015), mas sua tradução para o universo institucional, que produz as políticas públicas a partir de grades conceituais multilaterais, vem matizada por assimetrias de conhecimento e pela colonização do saber (PORTELA, 2015). Assim, que o processo disruptivo que caracteriza esse acontecimento não se restringe ao tempo cronológico do gatilho acionado, isto é, o tempo de duração de um episódio de enxurrada, de um escorregamento de massa, de um terremoto ou, ainda, do deslocamento de uma pluma radioativa ou de aparição de um vírus letal aos humanos. Engloba o tempo singular do sofrimento social de cada um dos que passam por tal adversidade, o dos revezes coletivos assim como o do ritmo de providências que a máquina pública, em diferentes esferas de poder e setores, tomará para reconhecer ou não, e reparar ou não, no todo ou em parte, a situação adversa e estressante com medidas de contingência (VALENCIO; VALENCIO, 2018). Ao serem tempos não exatamente sincrônicos, mas moldáveis por parâmetros subjetivos, organizacionais, socioculturais, econômicos, políticos e ambientais próprios, também as características dos gatilhos acionados para a ocorrência dessas circunstâncias trágicas são passíveis de interpretações diversas, desde as que se atêm aos elementos socioespaciais localizados do cenário aos que os procuram numa perspectiva mais abrangente situada na lógica econômica forjadora do conjunto de equívocos, negligências e fragilidades sociais. Por exemplo, Wanderley, Mansur e Pinto (2016) não identificaram como gatilho do colapso da barragem de Fundão, no município de Mariana/MG - o qual ocasionou o mais emblemático desastre ambiental dos últimos anos no Brasil -, as falhas na estrutura de engenharia, mas o identificaram nas deliberações que as empresas implicadas tomavam. As medidas de segurança de barragens que adotavam naquele empreendimento estariam atreladas ao comportamento instável e desfavorável ao mercado de commodities aos seus negócios, afirmam os mencionados autores e, continuam, mesmo quando o mercado lhes dava acenos alvissareiros, suas deliberações em relação às medidas de segurança das obras civis não foram aperfeiçoadas como as circunstâncias exigiam. Nessa chave socioeconômica, é possível que, noutros tipos de desastres, os gatilhos estejam nas ideologias anacrônicas dos governantes, na ganância dos rentistas, nas omissões técnicas de produção e manutenção de infrasistemas urbanos imprescindíveis a uma vida digna, nos frágeis escudos de amparo social, no desemprego estrutural, nos desafios ainda existentes na capacidade de articulação social para organizar e reivindicar mecanismos protetivos adequados. Vejamos, a seguir, duas ilustrações sobre tais gatilhos de natureza social. 


\subsection{O desastre silente na tardança dos infrassistemas: um caso mineiro}

Sob a conjectura de que a cidade permaneceria aberta a oportunidades de inclusão social, assim como favorável à luta pelo direto à moradia, o Brasil assistiu, nas últimas décadas, uma intensificação dos movimentos sociais dedicados à ocupação organizada de territórios urbanos, embora com a continuidade das ocupações irregulares de favelas. Ambos os processos de ocupação do solo ensejaram mobilização social complementar dos moradores em relação ao direito de acesso aos infrassistemas públicos de saneamento básico, energia elétrica e afins. Ocorre que as articulações sociais voltadas para a busca de legitimidade de um espaço de morar e de conquista de tais infrassistemas nem sempre são o bastante para endereçar articuladamente todas a políticas públicas de que os recém-chegados necessitam para comprovar, para si mesmos, que fazem parte do projeto de modernidade do qual a cidade é referência socioespacial. O conteúdo dos dispositivos que embasam as práticas da máquina pública, em seus três níveis de planejamento e operacionais - federal, estadual e municipal - é reiteradamente utilizado para colocar óbices à produção social destes lugares e de sua melhoria, produzindo-se interpretações diferentes das dos reivindicantes e reduzindo a expectativa destes de que suas estratégias de alcançar protagonismo social estejam sendo levadas a sério.

Amin (2014) refletiu centralmente sobre processos de territorialização de comunidades empobrecidas a partir do que ocorria numa metrópole da região sudeste do país, a capital mineira, Belo Horizonte. Ele se dedicou a observar como se entrelaçavam, ali, as demandas particulares e coletivas em relação à infraestrutura material e seus respectivos serviços de saneamento, energia, pavimentação de vias, coleta de lixo e outras. Desde uma mirada sociológica, acompanhou in loco rotinas de quatro comunidades - a saber, a das ocupações denominadas Dandara, Eliana Silva, Rosa Leão e Nossa Senhora de Fátima, cada uma em diferente fase de sua territorialização - para identificar a diversidade de mecanismos de agenciamento sociotécnico que (in)viabilizavam o acesso às referidas infraestruturas para integrar o lugar com a cidade imaginada; dito de outro modo, analisava se os pobres destes lugares estavam logrando êxito ou não no processo de legitimação de sua ocupação territorial. Como resultado de suas observações da dinâmica social do lugar e das transformações da paisagem, assim como entrevistando as lideranças comunitárias, moradores e agentes técnicos, Amin ponderou que o processo esbarrava reiteradamente em políticas públicas de reforçamento das desigualdades no acesso à cidade, sendo a complexidade dos acordos entre os próprios moradores um aspecto a ser considerado. Nem sempre havia convergência entre as motivações dos representantes de cada unidade residencial e seus compromissos com a luta coletiva para autoproduzir ou acessar benefícios para toda a comunidade. A própria precariedade econômica dos moradores, de motor para a ocupação ordenada ou desordenada, logo era passível de se converter em atomização social, cada morador dedicando o seu tempo prioritariamente a procurar por outras fontes de renda e a beneficiar seu lote do que manter compromissos solidários e de avanço de seus projetos comuns, resultando em levar à exaustão e ao desânimo líderes comunitários combativos. As práticas 
gradualmente individualistas também tinham uma justificação. Tal processo parecia social e economicamente penoso, desde a conversão de frágeis abrigos de madeira e plástico até a obtenção de trabalhos precários adicionais, os bicos, para a aquisição de material para erguer a aspirada casa de alvenaria; desde o constrangimento em acessar clandestinamente a água e a luz para satisfazer, em níveis mínimos, suas necessidades de dessedentação e higiene pessoal e da casa ao penoso enfrentamento do estigma social espelhado no modo de tratamento que as autoridades lhes conferiam quando tentavam convencê-las do seu direito à moradia e assim por diante.

Cada comunidade reagiu de um modo distinto ao longo do seu processo de constituição num contexto citadino que naturalizava as injustiças sociais, apontou Amin. Onde houve sucesso no protagonismo social, este foi marcado pela reiterada aliança entre moradores, destes com as suas lideranças e de ambos com assessores técnicos - como pesquisadores e estudantes - que dispunham de ferramental teórico e metodológico para auxiliar a comunidade num planejamento de ações de territorialização coadunado com as diretrizes de planejamento urbano estabelecido pela legislação, tais como no relativo à preservação de áreas verdes, não ocupação de áreas de risco geológico ou áreas de mananciais. Essa aliança foi destacada como sendo algo fundamental para neutralizar as resistências da máquina pública ao direito de morar ali reivindicado bem como para fortalecer as demandas comunitárias de infrasistemas pós-ocupação. Amin ressaltou quatros aspectos virtuosos nas comunidades que vinham obtendo maior êxito em suas demandas: (a) a combatividade política, na regularidade de reuniões e disposição dos moradores para assumir tarefas organizativas e de visibilização da sua luta por direitos territoriais coletivos, do que dependia os direitos individuais à propriedade do lote; (b) o apoio contínuo à liderança local em torno de um senso comum de justiça distributiva da terra, algo desafiador devido a dinâmica dos entraves surgidos a cada etapa do caminho, exigindo dos participantes a reformulação de seus acordos e processo no qual as lideranças também eram testadas em sua capacidade de negociação; (c) o exercício de sociabilidade com grupos técnicos, buscando um ponto de contato entre os seus diferentes saberes e linguagens para discutirem horizontalmente os desafios e possibilidades de ordenamento territorial e soluções de infraestrutura em benefício daquela coletividade e (d) a compreensão sólida que os moradores adquiriam de seu sentido de agência para pertencer a um determinado lugar - algo que havia sido negado àquelas pessoas até então -, o que era expressado através do cuidado mútuo, dos fluxos de pessoas que se auxiliavam mutuamente na construção simultânea de suas moradias. Trata-se aqui, como ocorre em outras comunidades do país, dos mutirões, onde os moradores se organizam para viabilizar desde o empréstimo de materiais e ferramentas ao preparo e distribuição de refeições; do oferecimento de suas habilidades construtivas para colaborar nas obras de fundação às de levantar juntos as paredes de uma moradia, montar o telhado, fazer as instalações elétricas, colocar contrapiso e assim por diante. A produção coletiva de moradias alimentaria o anseio por adiantar etapas de infraestruturas para ver a comunidade como um todo prosperar, como através de sistemas locais de saneamento. 
Por outro lado, Amin reporta que os insucessos no percurso se deviam ao frágil equilíbrio entre os interesses coletivos e individuais, refletidos quer na progressiva desconexão entre o plano idealizado e o da dinâmica concreta da ocupação. Havia o acúmulo de frustrações, quando as autoridades e os agentes técnicos dos serviços públicos de urbanização punham em suspenso os compromissos assumidos com as comunidades. Onde houve um ambiente de desconfiança mútua e de recusa à colaboração, mais as tensões nas relações de vizinhança se incrementavam, pondo a perder a mobilização para a conquista da infraestrutura desejada. Quanto mais ocorressem dissonâncias entre as visões e ações organizacionais dos subgrupos de residentes, entre estes e os dirigentes da ocupação, entre estes e as autoridades competentes, entre ambos e as facções criminosas emergentes, entre estas e os movimentos religiosos locais, maior a volatilidade do poder local. A atomização social aqui se traduzia em desrespeito ao desenho prévio dos lotes, conforme o que havia sido coletivamente planejado; no avanço da área edificada no lote em detrimento da manutenção das condições adequadas de percolação ou drenagem; no lixo orgânico e inorgânico jogado na rua, prática alheia aos pontos de disposição estabelecidos; nas brigas constantes entre vizinhos; no avanço da cultura do medo e da violência armada; no odor característico das valas de esgoto abertas em meio à ruas sem pavimentação; enfim, na estética do abandono, que favorecia o incremento das tensões entre o público e o privado, ressalta Amin. Essa deterioração socioambiental dava munição argumentativa aos setores bem estabelecidos da metrópole para criminalizar as ocupações, estigmatizar seus moradores, estimular conflitos locais, manipular o direito dos pobres de acesso aos bens e serviços públicos, além de pressionar por sua expulsão e os colocar no fim da lista de prioridades de atendimento na agenda pública, o que deixava claro que a luta simultânea pela tangibilidade da territorialização coletiva e individual, seguida por aquela de conquista da infraestrutura urbana, eram perpassadas pela dinâmica do ambiente econômico e democrático em que essa luta se inseria, concluiu o autor. Não é de admirar que estas comunidades esgarçadas sejam as mais suscetíveis às intempéries, e cujos riscos disseminados das estruturas e ambientais - iminente colapso de moradias, processo erosivos do solo e outros - sejam os argumentos técnicos para recomendam a interdição da área e a remoção das famílias dali.

Esse quadro ilustrativo nos leva, então, de volta aos gatilhos dos desastres. Sob uma perspectiva sociológica, são as dinâmicas sociais precedentes aos eventos, produzidas lentamente no recorte alargado do tempo histórico - e materializadas nas (im) possibilidades de inserção espacial, no (in)acesso a sistemas de objetos eficientes, de assimilação de (des)informação, nos modos de (des)socialização -, que fornecem as condições ótimas para confrontá-los como experiência disruptiva (ir)reparável. Ou seja, cada tipo de evento apresenta apenas um poder relativo de destruição/danificação sobre uma dada coletividade, pois é a organização social precedente - que aciona ou desativa, compartilha ou retém os recursos protetivos - que emoldura a severidades dos acontecimentos adversos. Eventos de natureza climatológica, hidrológica, geológica, tecnológica ou biológica - como estiagens prolongadas, inundações, 
escorregamentos de massa, colapso de estruturas, aparecimento de vírus letais aos humanos, dentre outros - têm potencial para desdobrarem-se em desastres. Porém, é no tempo de preparo interinstitucional prévio, como ainda na concertação social, que essa ameaça se realiza ou se dissipa. Nesses termos, não seria preciso esperar a ocorrência do evento para constatar o desastre. O desastre já estaria lá, de forma latente, esperando a gota d'água para transbordar. É desse copo, já quase transbordante, que as políticas públicas preparativas às catástrofes deveriam se ocupar. Entretanto, evitam fazê-lo, dado que os atores estatais sabem que isso implicaria em lidar com um vespeiro, mormente com os da concentração da renda, da especulação imobiliária, da prevaricação de agentes públicos, da corrupção e violências afins.

Em lugar dessa confrontação com os problemas sociopolíticos subjacentes à normalização da ocorrência de desastres, os agentes do Estado têm optado pelo caminho fácil. Qual seja, o da tentativa de ludibriar a realidade concreta, através de performances de preparação conciliatória entre atores que se encontram nas pontas opostas de um desastre iminente. De um lado, há apoio estatal aos atores econômicos que fabricam riscos ambientais, porque o benefício econômico imediato da inserção territorial destes, como a geração de emprego ou pagamento de impostos, é aquilo que será prioritariamente levado em conta. De outro, como assinalam Iossifova et al (2020), as políticas públicas ainda não se problematizaram a contento o modo de co-evolução dos diferentes infrassistemas urbanos e como isso pode estar contribuindo para incrementar a marginalização social, os riscos e os medos coletivos. Ademais, há infraestruturas que chegam num dado território não para servir à comunidade ali situada há tempos, mas aos recém-chegados, vizinhos incômodos, como grandes empresas que demandas pavimentação, eletricidade, água e esgoto para se instalarem, além de incentivos fiscais para ali permanecerem.

Por vezes, quando o Estado atravessa o lugar, buscando conciliação nas relações de vizinhança entre a comunidade empobrecida e o meganegócio próspero, os riscos socioambientais podem se ampliar e não serem contidos.

\subsection{A aceitação resignada de relações de vizinhança com meganegócios que produ- zem riscos $^{3}$}

Contemporaneamente, ao menos cinco componentes de riscos são observáveis, quais sejam:

(a) esses fenômenos estão sendo socialmente produzidos de um modo célere;

(b) há o surgimento de novos riscos sem que os precedentes tenham sido superados;

(c) os riscos são deflagrados e/ou manejados por um conjunto variado de atores e através de enredamentos territoriais e extraterritoriais simultâneos;

3 O conteúdo deste subitem corresponde à apresentação que a autora fez na Mesa-Redonda Desastres como indícios da crise do capitalismo, no âmbito do II Seminário Internacional Desnaturalização dos Desastres e Mobilização Comunitária, ocorrido em outubro de 2021, online. Uma versão mais detalhada deste item foi disponibilizada para uma publicação da Escola de Defesa Civil do estado do Rio de Janeiro. 
(d) há um amplo espectro de sentidos atribuídos aos riscos por essa gama de atores; por fim,

(e) o encontro frequente entre diferentes tipos de riscos tem resultado na metamorfose dos mesmos, o que os leva a escaparem dos protocolos de gerenciamento preestabelecidos.

Tais componentes apontam para o caráter transtemporal e transescalar dos riscos, o que coloca no centro da inquirição, técnica e científica, aquilo que Beck (2018) denomina como sendo as relações de definição, isto é, a disputa assimétrica entre intérpretes dos riscos para influenciar a formulação de políticas públicas no assunto. Os ganhadores, desleais, são anunciados pelos governantes como os únicos aptos a definirem o problema e prescreverem um modo particular de gerenciá-lo, pondo no status de irrelevância tudo o mais. Essa é uma atitude agourenta, porque anuncia a desatenção oficial para com os demais processos de fabricação de riscos que, embora olvidados, podem vir a ocorrer e a se somar com aqueles percebidos.

Se estamos caminhando numa Era do Imprevisto, na qual somos surpreendidos por uma sucessão de crises, que desfazem as nossas certezas sobre o mundo, os arranjos espaciais, sociais, econômicos e políticos precisam ser refeitos a todo o momento (ABRANCHES, 2017; BAUMAN, BORDONI, 2016). As relações de vizinhança fazem parte dessas novas instabilidades. Dentre as mais desafiadoras estão as que englobam os meganegócios extrativos e produtivos, os quais violentam a vida cotidiana das comunidades ao derredor, pondo-as em permanente estado de angústia devido aos riscos à saúde relacionados à poluição atmosférica e hídrica, a contaminação de solo e outros. O papel esperado do Estado, diante dessa relação assimétrica, é equalizá-la. Porém, por vezes o Estado intervém para reforçar a verticalidade dessa relação, sua assimetria. Desde a emissão de licenças de instalação e de operação para tais meganegócios até o modo de treinamento da comunidade caso haja um acidente na planta do empreendimento e que transborde para as áreas contíguas, o Estado age na qualidade dessa relação.

Os meganegócios se territorializam com base em documentação, ofertada ao Estado, que indica que todos os riscos possíveis relacionados à sua operação foram identificados e que as medidas de contingência que porventura se façam necessárias frente a um acidente, encontrarão todos os meios preparados para concretizá-las. Quando a narrativas empresariais calcam nessa promessa de controle a sua inserção territorial planejada, seus dirigentes convencem os agentes técnicos do setor público, os quais, então emitem licenças de operação e procedem fiscalizações periódicas. Porém, acidentes, desastres ou catástrofes que subitamente ali se desenrolam fazem desmoronar tais certezas, até então, irrefutáveis. Nas comunidades ao derredor, as vítimas sofrem danos multifacetados: físicos, sociais, materiais, psíquicos, econômicos e simbólicos. Enquanto isso, os operadores de ações setoriais de resposta à emergência são acionados. Mas, a concertação também apresenta percalços: defesas civis, bombeiros, o setor saúde, departamentos de obras públicas, serviços de água, de energia e de telefonia implicados têm cada qual, o seu ritmo e lógica. Todos se veem obrigados a alterar o seu elenco de prioridades nesta situação e urge, igualmente, reorientar as 
prioridades da vida comunitária. Ou seja, as precedentes certezas de controle sobre os riscos interfere em muito na qualidade de preparação dos segmentos que operam na resposta, bem como no das comunidades vizinhas, porque o quadro real é sempre mais complexo do que o previsto.

Um aspecto desse (des)preparo são as pactuações ambíguas que os órgãos operativos de resposta à emergência fazem com meganegócios, argumentando ser em prol do bem-estar das comunidades vizinhas ao empreendimento. Uma delas é a que se refere ao processo de naturalização da prática destes meganegócios apoiarem - financeira, técnica e materialmente -, estes órgãos sob o argumento de que, deste modo, estariam equalizadas as condições de se prover segurança humana dentro e fora do empreendimento. Porém, isso suscita certas alianças entre o público e o privado que suscetibiliza as comunidades a que ambos se comprometem a proteger. Ao investir no aparato tecnológico destes órgãos, como de defesas civis ou de bombeiros, o meganegócio bloqueia as críticas que estes possam fazer à sua instalação e operação, constrangimento que permite ao empresariado se sentir seguro o suficiente para afrouxar suas políticas contra acidentes, quando não uma circunstância propícia à reversão de papéis. Onde deveria haver distanciamento crítico do ente público - para lhe permitir preservar um repertório próprio e qualificado para prover a adequada regulação, monitoramento, fiscalização e responsabilização de agentes econômicos passíveis de descuidarem dos riscos que produzem -, se estabelece uma tal amalgamação cognitiva e de interesses que permite aos meganegócios, a certo ponto da relação estabelecida, tomarem as rédeas das formulações públicas de gerenciamento de risco e de resposta aos desastres, ainda que nos bastidores. Se essa estratégia é bem-sucedida, as autoridades públicas que adotam o receituário empresarial de visão e de controle sobre riscos passam a depender das lentes do ator inspecionado para fazerem a inspeção que lhes compete, num campo de visão cheio de pontos-cegos. Quanto mais a busca pela conciliação de interesses públicos e privados vai ganhando robustez nessa problemática relação de vizinhança, menos pressões de vigilância estatal são exercidas sobre os meganegócios, fomentando um ambiente permissivo que favorece incidentes ocasionais; estes, logo em seguida, se transformado em acidentes regulares e, depois, em desastres catastróficos.

Nesse contexto, exercícios simulados não estão precipuamente a serviço de equacionar os riscos efetivos, tampouco averiguar a sinergia entre riscos distintos que possam ter manifestação simultânea, tampouco testar um modus operandi de enfrentamento integral. Estão, sobretudo, a serviço de naturalizar a nova hierarquia de relações socioespaciais, na qual os atores que produzem os eventos-gatilho mais destrutivos são aqueles que, direta ou indiretamente, passam a ditar a nova ordem social, desde as regras de comportamento coletivo às intervenções no direito de habitar ao derredor, desde os objetos que moradores possam levar consigo numa evacuação compulsória às rotas de fuga que devam ser acessadas. As comunidades são as que devem ser treinadas para abandonarem o seu lugar de vivência, mas não lhes sendo possível o contrário, ou seja, obterem o apoio estatal para reivindicar o desmantelamento da planta que arrisca o bem-estar no lugar. Essa assimetria de fluxos, em meio ao qual se encontra o Estado, mostra quem define os termos da (des)proteção socioambiental. 


\section{As promessas democráticas em frangalhos}

As promessas democráticas, como as de propiciar condições de inclusão social, estão sendo reiteradamente desmentidas. A capacidade de investimento público está seriamente comprometida no Brasil, nos três níveis de governo, enquanto as suas políticas também conduzem aos desinvestimentos privados, além dos demais óbices que os dispositivos legais criam às saídas criativas que os trabalhadores inventam para sobreviver, quando já se sabem abandonados pelo Estado.

Ao estar dedicado a manter a máquina operando apenas para si mesma, nas repartições públicas onde as demandas dos subcidadãos não são bem acolhidas, vistas como um estorvo em meio à prioridade de reuniões sucessivas e de providências de lidar com a papelada a ser carimbada e despachada, o Estado brasileiro convenientemente vem deslocando para o mercado muitos dos seus afazeres. Contudo, isso empurra o país para um ciclo de políticas públicas disjuntivas, entre outras razões, porque o fatiamento dessas políticas para a gestão privada as coloca na grade de estratégias autônomas de obtenção de lucro a que cada um dos negócios está dedicado. Ali, a voz do cidadão não conta mais, pois esse, transmutado em consumidor dos serviços ou produtos do negócio privado, também vai descobrindo que a sua demanda deve prioritariamente se enquadrar ao planejamento da rentabilidade da empresa e dos interesses dos acionistas. Crises de abastecimento de água, de fornecimento de energia elétrica, de manutenção de estradas, de atendimento hospitalar e tantas outras se devem ao deslocamento do foco do novo gestor, no qual a satisfação do atendido é uma peça menor no tabuleiro.

Essa terceirização das funções públicas vai alcançando mansamente outras atribuições, dos serviços de limpeza das instalações ao de motoristas das autoridades e funcionários de alto escalão das repartições públicas, dos serviços de vigilância predial aos de segurança de dados institucionais. E, uma vez que ao Estado não haja muito a fazer diretamente, em vista de que a delegação de tarefas esteja regida por contratos de longo prazo com o setor privado e/ou com alocações de recursos orçamentários ou extraordinários já definidas, nada restou para ser conversado com a figura esvaziada do cidadão.

Esse contexto político, por um lado, incapacita o exercício de cidadania ativa, pois não é mais nos termos dos direitos universais que o enfrentamento com os negócios públicos, então privatizados, se dá ou tenha reconhecida a sua legitimidade; por outro, porque o esvaziamento dos canais de interlocução suscita tamanho sentimento de impotência política que produz também presas fáceis ao populismo de diferentes matizes ideológicos. Esse processo nutre a democracia de fachada, reduzida a processos eleitorais coadunados com novos modos de dominação econômica e social. No caso brasileiro, a crise econômica global de 2008, acionada pelo rompimento de bolhas especulativas no mercado americano, foi se agravando nos anos subsequentes e repercutiu sobre as contas públicas e, destas, sobre o ambiente político local. O cometimento de uma pedalada fiscal, ao ensejar uma mobilização política moralizadora que justificou a cassação do mandato de Dilma Rousseff, teve como efeito mais longevo preparar o ambiente institucional, nos três níveis de governo, para a inserção e enraizamento de uma cultura política de ultradireita, desdenhosa dos princípios democráticos. 
Uma vez instalada, a governamentalidade de ultradireita e a neoliberal se confundem, desacreditando o Estado como fonte para atender ao cidadão e desmantelando-o ao propugnar a aceleração das privatizações. Governantes regidos por essa orientação são escudados por grupos de parlamentares servis, do mesmo campo ideológico e da ala fisiológica, ao passo que a forma regular de comunicação pública passa a ser filtrada por seu séquito nas redes sociais e na amplificação de fake news, a fim de dar constância e legitimação a uma interpretação enviesada dos problemas sociais com os quais o governo precisaria lidar. Aparelhando o Estado para alinhá-lo e dar anteparo ao retrocesso democrático, na contramão cosmopolita - como através no estímulo a práticas econômicas baseadas na destruição de ecossistemas florestais, minando simultaneamente a perda da capacidade institucional de fiscalização ambiental, na ameaça sistemática ao modo de vida indígena, na desqualificação política dos movimentos sociais e criminalização de suas lideranças, no enfraquecimento das balizas científicas como norteadoras das decisões públicas, senão mesmo no desmantelamento das instituições científicas e retirada das condições de patrocínio à pesquisa - o período pós2016 tem sido marcado por uma gestão pública desastrosa, aferrada a concepções de mundo que obstruem a destreza administrativa necessária para lidar com os desastres que herda, com os que gera e com aqueles acionados desde fora, mas que lhes batem às portas e encontram caminhos para se desenrolar como catástrofe, sendo a pandemia de Covid-19 o mais emblemático deles. A incapacidade de lidar com a crise fiscal preexistente e agravada exigiu que a ultradireita encontrasse meios para driblá-la. E então, no final do ano de 2021, produziu, no âmbito federal, novas receitas de pedaladas fiscais, ainda mais robustas do que as que tinham sido por ela deploradas na década anterior, obtendo a aprovação do legislativo. Ao lográ-lo, a narrativa de moralização da máquina pública, antes adotada pelo mesmo grupo político, cai por terra, revelando-se apenas naquilo que sempre fora: um projeto de poder antidemocrático. Sob esse prisma, a (des)governança institucional não é mera inaptidão, mas um modus operandi que mina as relações de confiança em diversos níveis e temas da vida social. É desse modo que a autoridade política, constituída em suas características antissociais, mantém-se empenhada no uso espúrio das ferramentas institucionais para decompor, brutalizar e acuar a ação coletiva que luta por direitos universais. Assim, por meio das sucessivas instabilidades que provoca nos diferentes setores da sociedade, estes, digamos assim, governantes do desgoverno, instrumentalizam-se do exaspero social. Na pactuação com setores econômicos, religiosos e alas militares simpatizantes, que lhes são fiéis, evoluem no intento de legitimação de uma agenda plenamente autoritária, na provocação de um autogolpe. Ou seja, a democracia de fachada é vista como um jogo político oportuno para as primeiras investiduras contra o Estado; mas, tendo destruído muito do que era necessário para assentar um projeto de inclusão social, é jogo do qual, num dado ponto, se pode prescindir totalmente por meio de rupturas institucionais.

Logo, o Estado como um instrumento de integração de demandas sociais se torna um instrumento para recrudescer assimetrias sociais, desmanchar os pactos sociais prévios e propiciar catástrofes, como a que vimos no âmbito da gestão da saúde pública no contexto pandêmico que ocasionou a morte prematura de centena de 
milhares de brasileiros e gerou imenso grupo de sequelados pela Covid-19. Com as instituições públicas enfraquecidas, mais celeremente os atores sociais sobrantes dispersam-se em boias de salvamento individuais e de pequenos coletivos e interesses particularizados, perdendo de vista um horizonte comum de lutas, o que contribui para que as forças concentradas de ultradireita se vejam libertas de obrigações de atendimento a quaisquer preceitos da ordem social democrática. Os grupos sociais que perderam seu sentido de agência, ou que sequer o desenvolveram um dia, submergem no entrelaçamento da crise econômica, política e sanitária, pulverizados nesse desastre misto e incapazes de reação.

O rentismo é favorecido no ambiente de instabilidade política. Os especuladores veem nisso a oportunidade de pressionar pelo aumento dos juros, de aquecer artificialmente o mercado de imóveis, visto como um dos ativos seguros em tempos de crise, de obter vantagens com a desvalorização cambial, enfim, poder contar com a ação institucional para favorecer seus ganhos monetários. Circunstâncias de dominação econômica não-produtiva como essas podem ser, num horizonte alargado de tempo, o motor para deflagração de uma situação pós-social; isto é, de lenta, porém sólida, aprendizagem de atores morais para formas novas de mobilização que propugnam pela dignidade da pessoa humana (TOURAINE, 2011). Como a sucessão de crises vai pondo a nu que a lógica rentista corrói a vida social, mas também não poupa o Estado, a decretação de emergências financeiras encontra ambiente que suscita na população indagações crescentes acerca da máquina pública: Para que, afinal, nos serve a máquina pública? Assim, no mundo onde o dinheiro-mercadoria ganha precedência sobre todas as coisas, e os especuladores se distanciam moralmente das tragédias que eles produzem, alimenta-se a possibilidade de um ponto de virada (TOURAINE, 2011). Até lá, mais nuvens negras se avizinham no céu das relações sociais.

Quando as forças políticas em posições confortáveis de poder mistificam os autocratas, os limites de interpretação das leis se tornam mais elásticos. Mesmo sob um manto aparentemente democrático, o que fica tácito na produção de novos dispositivos legais é que a obrigação de votar não é correspondida à obrigação de prestar contas dos eleitos. Governantes passam a se dedicar aos seus projetos particulares e, apenas eventualmente, fazem algo a favor da coletividade para que sejam deixados em paz, conforme salientou Bourdieu (2014). O referido autor, no entanto, também pondera que tomar de assalto o Estado, num contexto no qual a sociedade está fragilizada, não desobriga os poderosos circunstanciais a promoverem tentativas de integrar-se com a nação no enfrentamento das grandes crises. Bourdieu traz, como exemplo, aqui providencial, o das epidemias de séculos anteriores, que exigiram das autoridades francesas uma sólida resposta de investimentos em rede esgotos, em tratamento de água e em serviços hospitalares adequados para o atendimento às classes perigosas. Não porque alguém se importasse com elas em seu sofrimento particular, diz ele, mas porque eram portadoras de micróbios e doenças passíveis de contagiar as classes dominantes, por seus canais comunicantes nas vias públicas, como empregados domésticos nas residências de alto padrão e afins. Sequer esse nível de solidariedade social mal disfarçada chegou a se revelar na crise aguda da Covid-19 no Brasil. 


\section{A pulsão catastrófica subjacente ao processo de acumulação}

Bauman e Bordoni (2016) ponderam que é esperado que o Estado proteja todos os seus cidadãos de suas desventuras e do medo das humilhações sob todas as suas formas. Porém, o Estado perdeu a capacidade de ofertar cuidado, de amparar as vítimas dos desastres que não foram evitados, de tomar decisões econômicas includentes, de prover os serviços sociais adequados. E, quanto mais impotente ele se torna, mas ele se afirma por meio da violência.

Os subcidadãos, tendo impossibilidades de se integrar à economia de mercado de modo pleno, nela se situam como um objeto a ser dilapidado. Ali, somente lhes é possível transitar pelas margens de empregabilidade, seja no trabalho informal ou não-qualificado, mas na sujeição constante aos riscos de desemprego e à situação de desalento; do atendimento público, que sistematicamente produz enquadramentos normativos que suprimem possibilidades de acolhimento de suas demandas relacionadas aos mínimos vitais e sociais. As portas não estão abertas para terem atendidos os seus reclames, como nos relacionados aos serviços de saúde e aquisição de medicamentos; à vaga em creche; à necessidade de uma cesta básica; ao apoio para o pagamento do transporte público; ao acesso a uma vaga num albergue; ao acolhimento de sua denúncia de violências físicas, psicológicas e morais ocorridas contra si e contra os seus; ao direito à moradia; à contestar o despejo, que os levam à situação de rua; à a saber como evitar a humilhação ditada pelas pressões de cobradores, que os levam a acessar crédito com juros estratosféricos no sistema bancário e cujo não pagamento redunda em penhora de bens de difícil recuperação; à orientação para evitar a recorrida exasperada aos sistemas informais de agiotagem, cujos juros, ainda mais impraticáveis quanto à capacidade de pagamento dos devedores, encontram na ameaça à sua integridade física o aviso final para que se virem e honrem aqueles compromisso financeiro. Enfim, a integração pelas margens é aquela onde as condições de interlocução com os agentes públicos e econômicos é dificultada, as portas apenas ocasionalmente abertas, fazendo-os definhar por completo. Assim, consumidor falho é tanto uma categoria elucidativa da desumanização forjada pela governamentalidade neoliberal (BAUMAN, 2005; LEMKE, 2017), a qual isenta o Estado de produzir redes dignas de proteção aos que se encontram no limite da sobrevivência, quanto exprime as distorções na configuração de encontro dos setores marginalizados com o Estado e deste com as facetas mais prósperas do capital, especialmente as mais espoliadoras de recursos ambientais e humanos.

Tais distorções, que vão da indiferença institucional ao sofrimento social à blindagem e servilismo estatal às fortunas pessoais e empresariais descompromissadas com o bem-estar coletivo, revelam o domínio das pulsões de morte que os interligam. De um jeito ou de outro, o sistema de crenças e de práticas econômicas corrosivas que articulam os três entes acima, institui a naturalização de vias de tráfego da riqueza em sentidos opostos, através do binômio estatal de encorajamento-impossibilidades que serve, respectivamente, aos grandes capitais, os quais flanam pelo mundo, e aos 
subcidadãos enraizados e apreensivos com seu futuro incerto. Porém, a convivência forçada num ambiente de injustiças distributivas explicita o modo cada vez mais inconvincente como o Estado pronuncia a defesa de princípios que amalgamariam interesses e direitos. Por exemplo, considere as bolhas especulativas no mercado imobiliário americano como práticas de agentes robustos e que estão imbuídas de riscos extremos. Quando eclodem, explicitam o desastre econômico de largo alcance que estavam aninhando enquanto trafegavam, simultaneamente, nos fundamentos e nas brechas da lei e da vigilância das instituições regulatórias. O que provocou indignação social, nessas circunstâncias, não foi apenas que os vultosos negócios inconsequentes ou inescrupulosos tenham passado abaixo do radar do Estado, inepto, ou melhor, desinteressado em gerar mecanismos de controle eficazes para pôr alguns limites à volatilidade do capital. Mas, que o Estado tivesse se mobilizado prioritariamente para uma missão de salvamento desses mesmos agentes econômicos cujas práticas, de testar os limites de tolerância social em relação à sua ganância, tiveram como consequência o rompimento das bolhas que eles mesmos provocaram (TOURAINE, 2011). O Estado o fez em detrimento da priorização de medidas diretas de recuperação econômica das milhares de famílias que, vítimas da bolha imobiliária, se viram sem emprego e sem condições de honrar compromissos creditícios relacionados à aquisição de seus imóveis. Despejadas de suas residências, sem alternativa de trabalho e abrigo, proliferaram as famílias que, do dia para a noite, tiveram que passar a morar dentro de seus veículos, quando os tinham, estacionados aqui e acolá, expondo de maneira vexatória a precariedade súbita de sua vida privada para os que testemunhavam o seu confinamento neste não lugar. Esse abandono é experiência social indelével do lado mais predatório do rentismo, assim como o foi aquele dos percalços enfrentados por sobreviventes à passagem do furacão Katrina, em Nova Orleans, no ano de 2005, para quem o sistema creditício imobiliário criou regras diferenciadas de análise de seu perfil de cliente, as quais impossibilitavam, quando fossem pobres e/ou negros, terem acesso aos recursos necessários para reconstruírem a sua moradia (BULLARD, 2006), higienismo socioeconômico para utilizar a catástrofe como oportunidade para viabilizar um plano célere de reurbanização favorável a novos investimentos imobiliários para os setores emergentes da sociedade (JON; PURCELL, 2018).

De um lado, quando a indignação social ante a crises como estas reduz-se a lamentos difusos ou a tentativas inócuas de agência, isso colabora para que tais crises se tornem sistêmicas. Quando Touraine (2011) indaga a razão pela qual são olvidadas as trovoadas que precedem as grandes crises, ele mesmo responde que isso dá porque a ordem social global marchou em direção à imposição da lógica rentista sobre os princípios dos direitos universais, permitindo ao rentismo produzir essas nuvens escuras enquanto vendem guarda-chuvas aos que podem pagar. Desse modo, não seria senão pela resistência do sujeito de direitos universais, na construção de um novo projeto de organização social e econômica, que algum horizonte de esperança poderia se revelar, o que converge com o caminho cosmopolita a que Beck se refere. 
De outro, quando resta nos desvalidos algum senso comunitário e de pertença, a sua reação organizada ante o escancaramento das injustiças sociais pode lograr êxito, tal como Jon e Purcell (2014) relatam no caso de Nova Orleans, onde algumas comunidades se articularam para planejar, nos seus próprios termos - e congregando em torno de suas causas diferentes atores técnicos, ongs, movimentos socias e afins para amplificar e orientar os seus recursos de voz -, a recuperação de seus bairros e, desde este ponto político de referência, pautaram a agenda pública de investimentos no local, similar às estratégias sociais exitosas em Belo Horizonte aludidas por Amin (2014).

Contudo, o desenrolar da pandemia de Covid-19, desde o início dos anos de 2020, quando reconhecida pela Organização Mundial da Saúde (OMS) como tal, acelerou o tempo e deslocou as atenções, retardando o incremento de críticas ao capitalismo. As condições banais de onde emergiram e espargiram um novo fator de perigo para a sobrevivência humana suscitou a necessidade de alterações súbitas e prementes na agenda de pesquisa científica assim como a sua imediata transposição para o ambiente de negócios, permitindo a formulação de contratos comerciais de longo prazo com governos de todo o mundo, a deflagração de inovações de produtos e de processos dentro de um ritmo incessante de atividade bem como o refinamento da logística de distribuição de insumos e/ou vacinas para as centenas de países simultaneamente demandantes. A apreensão social impôs constante recalibragem das posições governamentais sobre o assunto e de suas respectivas providências. Tais características de aceleração do tempo, para vencer a rapidez dos processos de contágio e seus desdobramentos em casos severos, a exigir atendimento de urgência acima da capacidade de suporte dos sistemas de saúde locais, como ocorreu em inúmeros países, incluindo o Brasil, confrontaram-se com o tempo lento no qual os pacientes graves e/ou suas famílias lutavam para lograr êxito no acesso a uma vaga de internação hospitalar; terem acesso a oxigênio e aos demais insumos que viabilizassem a intubação do familiar com o menor sofrimento físico possível; de reação orgânica e psíquica do paciente na experiência de sofrimento agudo e de adaptação frente às sequelas. Cada minuto que se arrastou, como no caso de Manaus, ganhou repercussão como escândalo social, expondo a inaptidão do Estado, nos seus diferentes níveis de governo, para lidar com crises agudas.

Tais circunstâncias pareceram se assemelhar, ou mesmo ultrapassar, a imaginação apocalíptica oriunda dos produtos culturais hollywoodianos (POHL, TOMŠIČ, 2021). Ante a tal similitude entre o universo experiencial fantasioso com o das ocorrências trágicas no plano da vida concreta, as certezas sobre o amanhã desabaram, só faltando os zumbis, conforme estes últimos autores apontam. A cada novo alarme, como no referente à ocorrência de mutações substantivas do coronavírus SARS-Cov2, as expectativas sociais de retorno da normalidade ruem enquanto as reações institucionais permanecem letárgicas, expondo reiteradas disjunções entre os tempos que regem a sociedade e a máquina institucional. A primeira experimenta adaptações ligeiras para manter sentidos para uma vida aspirada no futuro próximo enquanto a segunda se mantém dentro do ritmo normal do regime burocrático, como se o vírus obedecesse à sua racionalidade, não adentrasse às fronteiras nacionais e nem se propagasse aos 
finais de semana e feriados, quando as repartições públicas estão fechadas ${ }^{4}$. Dito de outro modo, o Estado age para sinalizar que suas deliberações prevalecem sobre a ordem das coisas, mas a ordem das coisas, no mundo contemporâneo, revela ao Estadonacional a incapacidade deste de reagir em conformidade com as exigências correntes da realidade vivida e de trânsito social global (BECK, 2018).

As experiências de lockdown coroaram a ideia de fim do mundo, o qual pareceu estar à espreita no contexto pandêmico e diante ao qual somente o capitalismo parecia sair ileso (POHL, TOMŠIČ, 2021). Assim, indagam esses autores, a que se deveria isso? Para respondê-lo, os mesmos notaram que essa sobrevida se deveu em alguns contextos nacionais, como o do Brasil, às decisões de cunho político que hierarquizaram as preocupações com proteção, estando aquelas relativas às garantias do modo rotinizado de funcionamento da economia doméstica acima das que se referiam à saúde pública. Em outras palavras, explicitando a precedência do princípio do prazer ao da realidade.

Tudo se passou como se coronapocalípse, ao ter sido absorvido e enquadrado pela lógica do sistema capitalista, suscitasse uma interpretação universalmente assimilável acerca do problema e cujas soluções institucionais desencadeadas fossem automaticamente coadunadas com o ambiente dos meganegócios. Isto é, sob o controle empresarial, seriam amainadas quaisquer outras interpretações acerca da vulnerabilidade social nas suas circunstâncias históricas e espaciais. Dito de outra forma, no bojo deste desastre catastrófico, o capital personificou-se como um novo e providencial Superman, alimentando o idílio de agência de segmentos econômicos impessoais, sem face (GIDDENS,1991), que nos redimiriam de ameaças globais, e não o motor que nos lança à beira de um abismo socioambiental e sujeitos a cataclismas. No mundo inteiro, as vacinas com marcas exclusivas do setor privado são as mais prestigiadas, numa concepção de que sejam mais confiáveis dos que aquelas que o setor público se esforçou em fazer, mesmo em parcerias, com os primeiros. A forma pura da racionalidade produtiva privada é o que parece nos convir em termos de crise, independendo se este abriu ou não mão de parte dos lucros em tais circunstâncias. Trata-se, assim, de um contexto global de impotência reflexiva, mencionado por Fisher (2017), no qual tanto a esterilização imaginativa quanto o testemunho direto da rendição do Estado a um ambiente de negócios, confirmam a naturalização da subcidadania dos que não podem sonhar com coisa alguma. Isto é, infere-se que não haja saídas para a crise ora instaurada senão sob a providência dos sujeitos sem face ou pela benevolência das classes superiores. A sociedade capitalista vai, assim, produzindo, ambiguamente, uma socialidade associal, isto é, cujas relações de poder disseminam concepções de mundo que esvaziam as tentativas de agência e desencadeiam pulsões destrutivas, sendo a ganância um elemento-chave (POHL, TOMŠIČ, 2021). Esta derivaria das pulsões humanas por obtenção incessante de prazer e se refletiria nas tendências antissociais

4 Reporto aqui, especificamente, o caso da emergência e dispersão global da variante de preocupação Ômicron, do referido coronavírus, cuja ciência das autoridades nacionais as fez deliberar pela restrição à entrada de voos oriundos de seis países africanos, a ser iniciado na semana subsequente à sua deliberação, deixando em aberto o final de semana no qual esse trânsito permaneceu permissível e demonstrou a falta de cuidado com o timing para vir a se caracterizar como parte constitutiva de um plano efetivo de contingência. 
de acumulação. O sucesso no controle de recursos dos quais dependem a coletividade permite aos gananciosos obtêm um gozo sistêmico a despeito das consequências catastróficas que causem, refletem os autores acima. Ao entranhar na ordem social que não apenas a tolera, como também a admira -, a ganância é um desejo insaciável de concentrar a posse de recursos que são necessários aos demais, ao invés de compartilhá-los. Desse modo, apresenta-se, simultaneamente, como prática econômica e prática política orientadas ao propósito de garantia de um gozo sistêmico. Manejando a dinâmica social como se fosse um polvo, em contorcionismos criativos que tanto driblam facilmente as barreiras legais, espaciais e morais quanto permitem que cada um dos seus tentáculos opere de um modo relativamente autônomo - visando à captura e contenção de recursos econômicos, políticos, ambientais e sociais variados -, a ganância é o deleite dos que assumem um controle incontestável sobre os excedentes de uma sociedade, ao espoliá-la.

Os gananciosos, com face ou sem face - dos bilionários exibicionistas, que mantêm o culto à sua personalidade e a rédea curta para controlar as decisões das corporações que conduzem, aos que adotam um perfil discreto, se ocultando em operações financeiras pouco rastreáveis, como as que envolvem as criptomoedas -, manobram, ainda, as condições de remuneração do dinheiro-mercadoria. A elevação do grau de endividamento de empresas e famílias, que é estimulada pelo mercado de crédito, os levam a tal ponto que passam a (sobre)viver unicamente para pagar as dívidas contraídas, capturados na armadilha dos juros escalonados; ou seja, efeitos associais da ganância que estrangula a economia em tempos de crise. Quanto mais incertezas há no contexto vivido, mais isso justifica as práticas rentistas, que drenam as possibilidades produtivas e de vida condigna, quebram pactos de confiança, desestruturam os pequenos negócios e famílias, os incapacitam, retiram-lhes condições para lidar com outras crises, transforma-os em zumbis. Quanto mais acuados, do que isso, os subcidadãos poderiam estar?

\section{Conclusões ${ }^{5}$}

Os desastres não são uma exterioridade à vida social. Pelo contrário, emergem de suas regularidades, como já o havia explicado Quarantelli (2015). Assim, a narrativa institucional de retorno à normalidade produz anseios coletivos, como também os anseios coletivos dão eco a tal narrativa institucional, de que seja viável um projeto civilizatório pautado no idílio de um recuo ao seu estágio de desenvolvimento em que o mundo parecia estar dando certo. Em termos psicanalíticos, porém metafóricos, seriam as regressões de comportamento para não ter que lidar com as dificuldades inerentes aos desafios de aprendizado exigidos naquela etapa da vida. Ao nos referirmos

\footnotetext{
5 A autora agradece à Editora, bem como aos Organizadores, pela possibilidade de publicação em Número Especial de tão prestigiado Periódico. Agradece, ainda, à Royal Society, pelo suporte ao projeto TOSSIB (Towards Sustainable Sanitation in India and Brazil), sob o Global Challenges Research Fund, através do grant CHL-R1-180122, que anteparou as indagações sobre os infrasistemas sanitários no Brasil aqui elencados. Por fim, agradece tanto ao CNPq, pela Bolsa Produtividade referente ao processo 315237/2020-1, quanto ao suporte da FAPESP, referente ao processo 2018/09900-8.
} 
ao comportamento coletivo de postergação dos enfrentamentos necessários, salientamos os perigos subjacentes, que são os de rendição às pulsões da morte, ou seja, a culminância do encurralamento social baseado na naturalização do ethos de predação. Contudo, é preciso considerar que, como um gigante com pés de barro, ao mesmo tempo em que o processo asocial de predação econômica e política é bem-sucedido, ganhando celeridade e escala, a destruição deixada à sua volta mina as suas bases de reprodução, esgotando as suas próprias fontes de poder.

Enquanto críticas ao modo de produção capitalista não estiverem no centro opinião pública dedicada a discutir a sucessão de crises, das quais os desastres fazem parte, os encurralados não encontrarão defesa perante os ataques progressivamente contundentes que sofrem diretamente ou que testemunham, neste último caso, visão aterradora que o faz presumir que este também haverá de ser o seu triste fim. O cerco é o ambiente social-associal característico da Era dos Desastres, quando os rompantes autoritários se revelam em maior crueza, desde a indiferença às demandas individuais e coletivas por garantia de condições de sobrevivência a sua coadunação com o modo mais virulento de mentiras e da acumulação não produtiva. Sucessivas crises econômicas, políticas e sociais, nalgum ponto, acionam gatilhos para desastres, incluindo os de dimensões catastróficas. Não é preciso que a chuva caia abundante para nos sabermos sem guarda-chuva, ou que ventos tormentosos assoprem para sabermos que o telhado é frágil. Algo pode ser feito antes da manifestação de tais eventos e é exigido pactuação social vigorosa para concretizá-lo.

A universalização dos fluxos econômicos não pode ser confundida com uma mundialização completa dos demais âmbitos da vida social, posto que os fluxos transnacionais de riqueza, embora tenham logrado crescente autonomia frente aos ditames dos Estados-nacionais, não dissolveram os modos nacionais de composição das classes sociais, das aspirações políticas de cada povo e das estruturas institucionais que delineiam e manejam as políticas públicas, mas compuseram com estas (SANTOS, 1996), reforçando-as ou as esgarçando em conformidade com as estratégias amplas e/ ou conjunturais de acumulação postas em curso. Vai daí, que a dinâmica rentista que se associa à concentração da informação e de dispersão de rumores, influencia desde as políticas nacionais de juros às de disseminação de fake news; desde as políticas de estímulo à produção de commodities às de especulação imobiliária urbana, as quais caminham prósperas e assentadas numa performance de desconexão com o aumento da insegurança alimentar e da população em situação de rua; desde o estrangulamento do mercado de trabalho aos reforços culturais ao consumismo, os quais reafirmam os patamares elevados de desemprego estrutural enquanto fazem proliferar a cultura do exibicionismo e da futilidade. Os subcidadãos trafegam por vielas cada vez mais estreitas, resultado de seus nexos perversos com a economia-mundo, os quais lhes são revelados num percurso tormentoso com escassas chances de fuga.

Por fim, os subcidadãos acuados na viela sem saída da acumulação perversa, vivenciam as derradeiras manifestações multiformes de brutalidade social que o recrudescimento dos desnivelamentos sociais produz, as quais incidem deleteriamente 
sobre o seu corpo, a sua saúde mental, a sua moradia, o seu trabalho, os seus vínculos sociais; enfim, comprometendo as suas condições de reprodução social. São abatidos por aqueles que extraem prazer e/ou benefícios em lhes ferir diretamente, por meio de suas políticas de exclusão social e práticas ativas de violência física, material, psíquica e simbólica, e porque encontram-se indisponíveis os outros tantos atores que poderiam participar de uma mobilização mais ampla para a reversão deste processo trágico, tais como os agentes públicos, cujos canais institucionais de acesso têm sido obstaculizados por filtros programáticos e burocráticos. As elites políticas, sociais e econômicas andam por demais atarefadas na atualização dos modos de expressão de sua indiferença social. Predam enquanto, simultaneamente, se eximem de qualquer responsabilidade sobre a tragédia social que produzem. Agem, assim, como as crianças lambuzadas de pedaços do bolo enquanto juram, de pé junto, que não foram elas que o comeram.

As rotas de fuga para os subcidadãos não estão dadas, uma vez que a lógica rentista e da democracia de fachada se associam para esvaziar quaisquer garantias de viabilização dos direitos universais. Uma alternativa é se embrenhar, num átimo, na escuridão, produzindo um caminho novo, rumo ao desconhecido, na inventividade produtiva, organizativa e política. Outra, é a tentativa de andança pelo caminho já trilhado, na saída enganosa do retorno à normalidade, que o levará ao mesmo encurralamento onde ora se encontra. De um jeito ou de outro, se mover adiante não é fácil. A musculatura das pernas paralisa; a voz falha e o grito fica retido dado que os estressores sejam imensos, não raro, insuportáveis. Súbito, padecem, quando tal experiência derradeira revela ser o sonho de inclusão social uma quimera, algo inalcançável. E, por sê-lo, o confronto assimétrico se revela em todo o seu vigor bárbaro. 


\section{Referências}

ABRANCHES, S. (2017). A Era do imprevisto: a grande transição do século XXI. Companhia das Letras, São Paulo, 2017.

ACSERALD, H. (2006). As cidades e as apropriações sociais das mudanças climáticas. Cadernos IPPUR, v. XX, n.1, p.77-106.

AMIN, A. Lively Infrastructure. Theory, Culture \& Society, v. 31 (7-8): 137-161, 2014.

ANAZAWA, T. M.; CARMO, R. L.. O risco construído: reflexões sobre o desastre ocorrido em Mariana, estado de Minas Gerais, em 2015. Vértices, v. 23, 234-255, 2021.

BAUMAN, Z. Vidas Desperdiçadas. Tradução de Carlos Alberto Medeiros. Zahar, Rio de Janeiro, 2005.

BAUMAN, Z.; BORDONI, C. Estado de crise. Tradução de Renato Aguiar. Zahar, Rio de Janeiro, 2016.

BECK, U. A metamorfose do mundo. Tradução de Maria Luiza X. de A. Borges. Zahar, Rio de Janeiro, 2018.

BOURDIEU, P. Sobre o Estado. Companhia das Letras, São Paulo, 2014.

BULLARD, R. D. Varridos pelo furacão Katrina: reconstruindo uma "nova" Nova Orleans usando o quadro teórico da justiça ambiental. IN HERCULANO, S.; PACHECO, T. (Orgs.). Racismo ambiental. FASE, Rio de Janeiro, 2006, 126-147.

COHN, G. Indiferença, nova forma de barbárie. IN NOVAES, A. (Ed.). Civilização e barbárie. São Paulo: Companhia das Letras, 2004, 81-90.

DUTRA, A. S. Gestão de desastres e serviço social: o trabalho de assistentes sociais junto aos órgãos municipais de proteção e defesa civil. Lumen Juris, Rio de Janeiro, 2018.

ELIAS, N. Sobre o tempo. Tradução de Vera Ribeiro. Zahar, Rio de Janeiro, 1998.

FISHER, M. Impotência reflexiva, imobilização e comunismo liberal. Traduzido por Rodrigo Gonsalves. LavraPalavra. Trecho do livro Capitalist Realism: Is there no alternative? ZeroBooks, 2017. Disponível em: https://lavrapalavra.com/2017/08/25/impotencia-reflexiva-imobilizacao-e-comunismo-liberal/ Acesso em: 02 de fevereiro de 2018.

GIDDENS, A. As consequências da modernidade. Editora UNESP, São Paulo, 1991. 
IOSSIFOVA, D. et al. Desigualdades infraestructurales en ciudades fragmentadas. Transformando infra-sistemas para la salud pública. IN Delgado Ramos, G.C.; RAMOS, D.L. (Orgs) Las ciudades ante el COVID-19: nuevas direcciones para la investigación urbana y las políticas públicas. Plataforma de Conocimiento para la Transformación Urbana, Ciudad de Mexico/DF, 2020, v. 1, 78-89.

JON, I.; PURCELL, M. Radical resilience: autonomous self-management in post- disaster recovery planning and practice. Planning Theory \& Practice, v.19, n.2, 235-251, 2018. Disponível em: https://doi.org/10.1080/14649357.2018.1458965. Acesso em: 14 de março 2019.

LEMKE, T. Foucault, governamentalidade e crítica. Tradução de Eduardo A. C. Santos. PLURAL, Revista do Programa de Pós-Graduação em Sociologia da USP, São Paulo, v. 24.1, 194-213, 2017.

LEVITSKY, S.; ZIBLATT, D. Como as democracias morrem. Tradução de Renato Aguiar. Zahar, Rio de Janeiro, 2018.

MARQUES, L. Capitalismo e colapso ambiental. 3.a ed. revista e ampliada. Ed. Da Unicamp, Campinas, 2018.

MATOS, O. C. F. Cerimônias da destruição. IN NOVAES, A. (Org.). Civilização $\boldsymbol{e}$ barbárie. Companhia das Letras, São Paulo, 2004, 281-299.

OLIVEIRA, S.S. Experiência e produção de saberes: possibilidades de superação das vulnerabilidades: reflexões acerca do desastre da região serrana do Rio de Janeiro. IN SIQUEIRA, A. et al (Orgs.) Riscos de desastres relacionados à água: aplicabilidade de bases conceituais das Ciências Humanas e Sociais para a análise de casos concretos. RiMa Editora, São Carlos, 2015, 291-309.

PAULA, K.T.; RODRIGUES, F.R.N.; LISBOA, N.M. Miopatia por captura em aves revisão de literatura. Anais do II WildLife Clinic Congress, 2a edição, maio de 2021. Disponível em: https://eventos.congresse.me/wcc/resumos/13606.pdf. Acesso em 30 de novembro de 2021.

POHL, L.; TOMŠIČ, S. O sistema capitalista como uma máquina de gozo com consequências catastróficas. IN E. T. Harper e D. Specht (eds) Imagining apocalyptic politics in the Anthropocene. Tradução do capítulo por Eleutério Prado. Routledge, Londres, 2021. Disponível em: https://aterraeredonda.com.br/a-pulsao-catastrofica/?utm_term=2021-11-24\&doing_wp_cron=1637783956.365712881088256835937. Acesso em: 24 de novembro de 2021. 
PORTELA, S. A liberdade se equipara à vida. IN SIQUEIRA, A. et al (Orgs) Riscos de desastres relacionados à água: aplicabilidade de bases conceituais das Ciências Humanas e Sociais para a análise de casos concretos. RiMa Editora, São Carlos, 2015, 187-203.

QUARANTELLI, E. Uma agenda de pesquisa do século 21 em ciências sociais para os desastres: questões teóricas, metodológicas e empíricas, e suas implementações no campo professional. Tradução de Raquel Brigatte. O Social em Questão, Rio de Janeiro, Ano 18, n. 33, 2015, 25-56. Disponível em: http://osocialemquestao.ser.puc-rio.br/cgi/cgilua.exe/sys/ start.htm?infoid=375\&sid=44 Acesso em: 04 de maio de 2016.

SANTOS, B. S. O fim do império cognitivo: a afirmação das epistemologias do Sul. Autêntica Editora, Belo Horizonte, 2019.

SANTOS, M. Metamorfoses do espaço habitado. 4.a edição. Hucitec, São Paulo, 1996.

SIQUEIRA, A. M.M.; MALAGODI, M.A.S. Desastres e remoções em Campos dos Goytacazes, RJ: o caso de Ururaí. In: LEITE, A. F.; GOMES, M. A. (Orgs.). Dinâmica ambiental e produção do espaço urbano e regional no Norte Fluminense. Essentia, v.1, 35-66, 2013.

TAVARES, M.C. O grande salto para o caos. Zahar, Rio de Janeiro, 1985.

TOURAINE, A. Após a crise: a decomposição da vida social e o surgimento de atores não sociais. Tradução de Francisco Morás. Editora Vozes, Petrópolis, 2011.

VALENCIO, N.; SIENA, M.; MARCHEZINI, V. Abandonados nos desastres: uma análise sociológica de dimensões objetivas e simbólicas de afetação de grupos sociais desabrigados e desalojados. Conselho Federal de Psicologia, Brasília, 2011.

VALENCIO, N. Para além do 'dia do desastre’': o caso brasileiro. Ed. Appris, Curitiba, 2012.

VALENCIO, N.; VALENCIO, A. (2018). O assédio em nome do bem: dos sofrimentos conectados à dor moral coletiva de vítimas de desastres. Lumina, v.12, p.19-39.

VILA, L.G. Midazolam no estresse por contenção em aves silvestres. Dissertação de Mestrado em Ciência Animal. Universidade Federal de Goiás. Escola de Veterinária e Zootecnia. Programa de Pós-Graduação em Ciência Animal. Goiânia, 2015. Disponível em: https://repositorio.bc.ufg.br/tede/handle/tede/5054. Acesso em: 30 de novembro de 2021.

WANDERLEY, L.J.; MANSUR, M.S; PINTO, R.G. Avaliação dos antecedentes econômicos, sociais e institucionais do rompimento da barragem de rejeito da Samarco/ Vale/BHP em Mariana (MG) IN MILANEZ, B; LOSEKANN, C. (Orgs). Desastres no Vale do Rio Doce: antecedentes, impactos e ações sobre a destruição. Folio Digital: Letra e Imagem, Rio de Janeiro, 2016, 39-87. 